\title{
Heritage Engagement and Subjective Well-Being in the European Union
}

\author{
Victoria Ateca-Amestoy $1, *\left(\mathbb{D}\right.$, Anna Villarroya ${ }^{2,3}$ and Andreas Joh. Wiesand ${ }^{4}$ \\ 1 Department of Economic Analysis, University of the Basque Country UPV/EHU, 48015 Bilbao, Spain \\ 2 Department of Economics, University of Barcelona, 08014 Barcelona, Spain; annavillarroya@ub.edu \\ 3 Centre of Research in Information, Communication and Culture (CRICC) University of Barcelona, \\ 08014 Barcelona, Spain \\ 4 European Institute for Comparative Cultural Research (ERICarts), 50999 Cologne, Germany; \\ wiesand@ericarts.org \\ * Correspondence: victoriamaria.ateca@ehu.es
}

Citation: Ateca-Amestoy, V.;

Villarroya, A.; Wiesand, A.J. Heritage Engagement and Subjective Well-Being in the European Union. Sustainability 2021, 13, 9623.

https://doi.org/10.3390/su13179623

Academic Editors: Ana Pastor Pérez, David Barreiro Martínez and Eva Parga Dans

Received: 12 July 2021

Accepted: 24 August 2021

Published: 26 August 2021

Publisher's Note: MDPI stays neutral with regard to jurisdictional claims in published maps and institutional affiliations.

Copyright: (c) 2021 by the authors. Licensee MDPI, Basel, Switzerland. This article is an open access article distributed under the terms and conditions of the Creative Commons Attribution (CC BY) license (https:// creativecommons.org/licenses/by/ $4.0 /)$.

\begin{abstract}
In this paper, we explore the relationship between different ways of getting engaged with cultural heritage and life satisfaction. Using data from a representative sample of the population of the 28 members of the European Union in 2017 collected in the Eurobarometer 88.1 (2017), we explore the relationship between use and non-use values and individual subjective well-being measured as life satisfaction. We present the results derived from the estimation of an ordered probit model where life satisfaction is a function of living near to heritage resources to represent non-use values, different ways of heritage participation (tangible, intangible, digital, and volunteering), and the usual explanatory variables that have been found to be predictors of life satisfaction. Our results indicate that the chances of being more satisfied with ones' life increase with volunteering activities, with visits to heritage institutions, and with digital engagement. These findings contribute to a better understanding of the multifaceted values of heritage.
\end{abstract}

Keywords: cultural heritage; Eurobarometer 88.1; use and non-use values; heritage participation; tangible; intangible and digital cultural heritage

\section{Introduction}

This article seeks to stimulate reflection on the benefits that individuals can derive from cultural heritage, among them, the alternatives of getting engaged with heritage, through visiting tangible heritage sites or practicing traditional skills. Particularly, it aims to assess whether cultural heritage itself generates (subjective) well-being or if the interactions that establish a vehicle for its enjoyment are needed. Subjective well-being and happiness research are empirically driven approaches and policy-motivated, in the sense that they are aimed at achieving a "better life", while at the same time enabling deeper insights on how human and social choices are based on values assessments. Over the past 20 years, the concept of values has been increasingly located at the heart of theoretical discourses on heritage [1] (p. 148). A contemporary, outward-looking perspective of societal values, focused on uses and functions of heritage places generated by a broad range of society-wide processes external to conservation, has emerged over the last years. This societal-value perspective brings to the fore broader forces forming the contexts of heritage places as well as the non-heritage functions of heritage places [2].

When specifically considering how cultural heritage can contribute to well-being, one has to recognize that this is a multi-sided social construct that is valued because of both its intrinsic values and its potential to deliver benefits to individuals and the whole society (commonly known as "instrumental" values). As an extension of the economic approach to natural resources and environmental goods, both use and non-use values are recognized in heritage elements. Use value is derived by the individuals that access those elements and 
thus enjoy a direct use experience. However, individuals may appreciate heritage on other grounds, as they may derive utility from this cultural capital even if they did not directly enjoy their experiences, by means of option, existence, or bequest values (capturing the possibilities of using it in the future, the intangibles from which the society benefits as a whole, and the possibilities of future generations accessing it, respectively, [3] (p. 13)). Cultural heritage is also multifaceted in the sense that there are many goods and services which are relevant elements valuable for their communities, inherited from the past (even the recent past), and in the sense that different ways of engagement may induce different benefits [3,4]. Typically, a distinction is made between tangible, intangible, and digital heritage [5] (p. 1).

In the European Union context, cultural heritage is called to be a driver for more innovative and resilient societies and for social cohesion, as stated in the New Agenda for Culture adopted by the European Commission in May 2018 [6] (p. 29). Apart from stimulating effects on the economy $[7,8]$, the promotion of cross-border mobility through cultural tourism can create bonds between citizens, enhance mutual understanding, and build a shared identity that relies on common values [6] (p. 11). Recent analysis highlights the interesting relationship between cultural tourists or travellers and cultural participation, with new heritage audience profiles linked to "constantly occasional museum attendance" [9]. Similar to other forms of leisure activities, cultural heritage engagement is driven by intrinsic motivation, so it is expected to have a positive effect on subjective well-being and to contribute to the production of "relational goods". Nevertheless, its beneficial effects for well-being are somehow taken for granted and more research and evidence-based analysis is needed. UNESCO [10] identified "a growing body of studies that demonstrate the importance of participation in cultural activities and sport to emotional and physical health, to social capital, cohesion and neighbourhood" but to date, there is no consolidated body. The potential of heritage to deliver benefits also reflects in more aggregated or societal outcomes. In fact, Stiglitz, Sen, and Fitoussi remark in their influential report the relevance of quality leisure activities and environmental resources to explain differences in well-being and differences in the progress of societies [11].

In this paper, we explore the association between different ways of engagement with cultural heritage and life satisfaction. As it is quite common within the economic analysis of well-being, we use life satisfaction, happiness, and (subjective) well-being as synonyms [12]. To do so, we draw on data derived from the Eurobarometer 88.1 (2017) conducted via a representative sample of the population in 28 member states of the European Union. This paper is structured as follows: firstly, a brief review of the literature sheds light on the different dimensions and methods. Secondly, the dataset and method are described. Finally, the results concerning the relationship between subjective well-being and heritage are presented and discussed, underlying the possible policy implications of our findings and proposals for future research.

\section{Subjective Well-Being and Cultural Heritage}

There is a growing body of empirical research exploring the influence of individual engagement with cultural heritage on individual well-being [13-15]. Most of the studies focus on the influence of participation in cultural heritage by means of access (visits) or active practice or volunteering, and compare it either with functional indicators (health, for instance) or with hedonic and evaluative data (life satisfaction or happiness). These dimensions recall what the OECD identifies as 'quality of life' factors, 'how well people are and how well they feel, what they know and how healthy and safe their places of living are' [16]. It also refers to one of the four principles of the Faro Convention on the value of cultural heritage for society, namely improving quality of life through heritage [17].

Some of the most relevant previous research has been conducted with representative samples of the population of European countries. In pioneering research, Fujiwara et al. [18] estimated the value associated to participation and visits to different types of tangible heritage by relating the changes in subjective well-being associated to heritage access 
with comparable changes derived from income increases. Wheatley and Bickerton [19] concluded that increasing the visits to heritage sites contributes to positive changes in life and health satisfaction. Bryson and MacKerron [20] explored the links between individuals' well-being measured momentarily at random points in time, concluding that arts activities, including going to exhibitions or museums, are positively related to happiness. Results by Hand [21] suggested positive subjective well-being effects at lower levels of happiness, with these effects presenting diminishing returns at higher levels. Fancourt and Baxter [22] analyzed the effect of arts and heritage engagement on health-related outcomes as measures of eudaimonic well-being, the functional dimension. Grossi, Tavano Blessi, and Sacco [23] investigated the effect of visual aesthetical experiences in a heritage site over biological (stress reduction) and psychological (well-being enhancement) responses, finding noticeable impacts. These studies further revealed differences in the relationship between heritage engagement and well-being for different groups of the population: bigger for people who reported a poor health status [18]; more relevant for older volunteers in museums and archives on community heritage organizations [24].

Further benefits may be derived from cultural heritage, as there are externalities of consumption that, for instance, create joint symbolic meaning. There is evidence of a positive association between cultural participation and social cohesion ([25] in the Netherlands) and between participation in arts and cultural activities and participation in civic life ([26] in Italy). Drawing on the "Aspetti della Vita Quotidiana" (Aspects of Daily Life) (AVQ) Survey, conducted on an annual basis by the Italian National Institute of Statistics (ISTAT), [26] (p. 657) study confirms that participation in cultural heritage and other art and cultural activities is highly correlated with civic engagement. Results also confirm that cultural venues such as museums, heritage sites, and art galleries, which are increasingly adopting digital technologies or gamified approaches, help transmit new knowledge or context for civic action to broader and "unusual" audiences [26] (p. 676).

Social cohesion is also related to many other communitarian outcomes, such as the sense of place and sense of belonging and the increased accessibility to heritage in more diverse forms: digital, physical, linguistic, by means of visits, and by charitable engagement of volunteers and donors. The positive effects of direct involvement at the individual level would not only derive from the intrinsic positive effect of engagement and enjoyment of the experience, but also from the enhancement of personal capabilities [27]. In this sense, diverse positive effects may arise from volunteering, as it benefits not only heritage organizations but also individuals that donate their time to them and may be rewarded by pleasant experiences ([28] in the European Union). Along with these individual benefits and these societal outcomes, the European New Agenda for Culture incorporates the political aim of mainstreaming the 'participatory governance' of cultural heritage an "innovative, people-centered and forward-looking approach" to facilitate access and shared responsibility of heritage by institutions and citizens and to achieve societal benefits [29]. To be sure that participatory practices do not become a simple "cosmetic device entrenched in renewed techno-bureaucratic procedures" [30] (p. 314), a better understanding of values and benefits is needed. Particularly, if models such as the participatory governance of cultural heritage are to be successfully promoted by public institutions, more needs to be known about the drivers and barriers for individuals to encourage true participatory practices and to get them engaged in more intense ways than mere visits [28].

It is difficult to assess and quantify the non-use values of cultural heritage assets, those that determine that an individual can value some assets even if no direct fruition is derived because of their consumption. Individuals put a value to having the option to access those elements in the future themselves (option value) or future generations (bequest value), and to the symbolic values that create prestige and identity (existence). The studies by Bakhshi et al. [31], Fujiwara et al. [32], and Del Saz-Salazar et al. [33] are remarkable attempts to consider the happiness approach to consider non-use values of heritage, making empirical exercises where results derived from state-of-the-art contingent valuation techniques are compared with the life satisfaction approach for heritage institutions in the UK and in Spain. 
An alternative to the happiness approach and to the traditional contingent valuation is provided in Sanetra-Szeliga and Górniak [34], who conducted research on the relationship between infrastructure projects in the field of culture, including cultural heritage, on the life satisfaction of its residents. For the Małopolska region (Poland), these authors found that over half of the inhabitants involved in the survey registered an overall increase in their sense of life satisfaction, sense of attachment, and pride of residing in the region following the investment.

The availability of heritage is not only physical but also related to the awareness and the individual and collective recognition of heritage values in the built and intangible landscape [8]. No matter if individuals access their heritage or not, the presence of heritage resources and of related activity in their region could also affect their perceived quality of life. In fact, the place where people live was also found to be related to well-being. With an international perspective and making use of the European Social Survey, Piper [12] found a happiness penalty associated with living in Europe's capitals. Steiner, Frey, and Hotz [35] analyzed whether hosting the European Capital of Culture had an impact on regional economic development and the life satisfaction of the local population, finding a negative effect on the well-being of the residents during the event. Dissatisfaction might be due to high levels of public expenditure, transport disruptions, general overcrowding, or an increase in housing prices ([35]: 29). The negative effects linked to over-tourism have recently been discussed in Adie et al. [36] and Adie and Falk [37], where the perceptions of cultural heritage as a driver of economic prosperity and the threads of over-tourism are jointly explored.

Table 1 presents a synthesis of the review presented in this section. The purpose is to illustrate the diverse dimensions of heritage and heritage engagement that have been studied so far, the coverage of performed analysis, and the methods and results that will be considered in our empirical exercise. 
Table 1. Summary of previous studies exploring the influence between individual engagement with cultural heritage and individual well-being.

\begin{tabular}{|c|c|c|c|c|c|c|}
\hline Authors & Geographical Scope & Source of Evidence & Focus on & Aims & Methods & $\begin{array}{l}\text { Main Results Relevant for Our } \\
\text { Research }\end{array}$ \\
\hline $\begin{array}{l}\text { Steiner, } \\
\text { Frey, and } \\
\text { Hotz (2013) }\end{array}$ & $\begin{array}{l}14 \text { nations (Belgium, } \\
\text { Denmark, Finland, France, } \\
\text { Germany, Great Britain, } \\
\text { Greece, Ireland, Italy, } \\
\text { Luxembourg, Netherlands, } \\
\text { Portugal, Spain, and Sweden) } \\
\text { and 24 ECOC (European } \\
\text { Capital of Culture) }\end{array}$ & $\begin{array}{c}\text { The Mannheim } \\
\text { Eurobarometer Trend file } \\
\text { (1970-2002.) This compilation } \\
\text { offers unified data from } 86 \\
\text { Eurobarometer surveys } \\
\text { conducted in } 18 \text { European } \\
\text { nations in the time period } \\
1970 \text { to } 2002 \text {. }\end{array}$ & $\begin{array}{l}\text { Europe's capital } \\
\text { cities }\end{array}$ & $\begin{array}{l}\text { Analyze whether hosting the } \\
\text { European Capital of Culture has } \\
\text { an impact on regional economic } \\
\text { development and the life } \\
\text { satisfaction of the local } \\
\text { population. }\end{array}$ & $\begin{array}{l}\text { Difference-in-difference } \\
\text { estimations }\end{array}$ & $\begin{array}{l}\text { A negative effect on the well-being of } \\
\text { the regional population during the } \\
\text { event was found. Since no effect was } \\
\text { found before the event, reverse } \\
\text { causality and positive anticipation } \\
\text { could be ruled out. The negative effect } \\
\text { during the event might result from } \\
\text { dissatisfaction with the high levels of } \\
\text { public expenditure, transport } \\
\text { disruptions, general overcrowding, or } \\
\text { an increase in housing prices. }\end{array}$ \\
\hline $\begin{array}{l}\text { Fujiwara } \\
\text { et al. (2014) }\end{array}$ & United Kingdom & $\begin{array}{c}\text { Wave } 2 \text { of Understanding } \\
\text { Society (2010-2011), a } \\
\text { nationally representative } \\
\text { sample of 40,000 households } \\
\text { conducted annually in a panel } \\
\text { format. }\end{array}$ & $\begin{array}{l}\text { Cultural } \\
\text { engagement and } \\
\text { sport participation } \\
\text { (Museums/libraries } \\
\text { /heritage sites visits } \\
\text { included) }\end{array}$ & $\begin{array}{l}\text { Identify the impacts of culture } \\
\text { and sport engagement on } \\
\text { individuals' well-being. } \\
\text { Estimate monetary values for } \\
\text { those well-being impacts using } \\
\text { the Well-being Valuation } \\
\text { approach. }\end{array}$ & Ordinary least squares (OLS) & $\begin{array}{l}\text { A significant association was found } \\
\text { between frequent library use and } \\
\text { reported well-being. } \\
\text { For the visits model to the libraries, } \\
\text { museums, and heritage sites, sample } \\
\text { sizes were substantially reduced due to } \\
\text { a high rate of non-response. According } \\
\text { to the authors, with more data, then, } \\
\text { the positive effects of visits to museums } \\
\text { and heritage sites on life satisfaction } \\
\text { may become statistically significant. }\end{array}$ \\
\hline $\begin{array}{l}\text { Bakhshi } \\
\text { et al. (2015) }\end{array}$ & $\begin{array}{l}\text { Natural History Museum } \\
\text { (NHM) and Tate Liverpool } \\
\text { (TL) in the United Kingdom }\end{array}$ & Surveys & Museums & $\begin{array}{l}\text { Provide a comprehensive } \\
\text { subjective well-being } \\
\text { investigation and valuation of } \\
\text { NHM and T visitation using a } \\
\text { number of complementary } \\
\text { well-being approaches. }\end{array}$ & $\begin{array}{l}\text { Two valuation techniques-stated } \\
\text { preference methods and the } \\
\text { well-being valuation approach. }\end{array}$ & $\begin{array}{l}\text { In both institutions, there is a strong } \\
\text { positive association between activities } \\
\text { at the institution and momentary } \\
\text { well-being indicators, measured as } \\
\text { how happy people feel and their sense } \\
\text { of purpose. This is after controlling for } \\
\text { a range of other factors that impact on } \\
\text { momentary well-being. }\end{array}$ \\
\hline $\begin{array}{l}\text { Piper } \\
\text { (2015) }\end{array}$ & $\begin{array}{l}\text { Isolating the capital city was } \\
\text { possible for } 15 \text { countries } \\
\text { (Austria, Belgium, Bulgaria, } \\
\text { Cyprus, Czech Republic, } \\
\text { Denmark, France, Germany, } \\
\text { Great Britain, Greece, Ireland, } \\
\text { Portugal, Spain, Sweden, and } \\
\text { the Ukraine). }\end{array}$ & $\begin{array}{c}\text { European Social Survey (ESS), } \\
\text { first } 4 \text { ESS rounds which cover } \\
2002 \text { to } 2008 \text {. }\end{array}$ & $\begin{array}{l}\text { Europe's capital } \\
\text { cities }\end{array}$ & $\begin{array}{l}\text { Investigate in three steps } \\
\text { whether there is an association } \\
\text { between happiness and living in } \\
\text { one of Europe's capital cities. }\end{array}$ & $\begin{array}{l}\text { The first step is a raw unadjusted } \\
\text { correlation assessment. } \\
\text { The second step is the addition of } \\
\text { socio-economic controls which } \\
\text { (overall). } \\
\text { The third step adds environmental } \\
\text { factors and perceptions (safety of } \\
\text { local area, worries about crime, for } \\
\text { example) to control for potential } \\
\text { confounding factors. }\end{array}$ & $\begin{array}{l}\text { Overall, there is a happiness penalty } \\
\text { associated with living in Europe's } \\
\text { capitals, though this result is } \\
\text { dominated by a few particularly } \\
\text { unhappy capitals. }\end{array}$ \\
\hline
\end{tabular}


Table 1. Cont.

\begin{tabular}{|c|c|c|c|c|c|c|}
\hline Authors & Geographical Scope & Source of Evidence & Focus on & Aims & Methods & $\begin{array}{l}\text { Main Results Relevant for Our } \\
\text { Research }\end{array}$ \\
\hline $\begin{array}{l}\text { Bryson and } \\
\text { MacKerron } \\
\quad(2017)\end{array}$ & United Kingdom & $\begin{array}{c}\text { Mappiness } \\
\text { (www.mappiness.org.uk), } \\
\text { which permits individuals to } \\
\text { record their well-being via a } \\
\text { smartphone. The data contain } \\
\text { more than a million } \\
\text { observations on tens of } \\
\text { thousands of individuals in } \\
\text { the UK, collected since } \\
\text { August } 2010 \text { to September } \\
2011 \text {. }\end{array}$ & $\begin{array}{l}39 \text { activities } \\
\text { individuals engage } \\
\text { in, with the } \\
\text { exception of being } \\
\text { sick in bed } \\
\text { (exhibition, } \\
\text { museum, library } \\
\text { visits included) }\end{array}$ & $\begin{array}{l}\text { Explore the links between } \\
\text { individuals' well-being } \\
\text { measured momentarily at } \\
\text { random points in time and their } \\
\text { experiences of paid work. }\end{array}$ & Correlations, simple OLS model. & $\begin{array}{l}\text { Arts activities, including going to } \\
\text { exhibitions or museums, are positively } \\
\text { related to happiness. }\end{array}$ \\
\hline $\begin{array}{l}\text { Cantillon } \\
\text { and Baker } \\
(2018)\end{array}$ & Australia & $\begin{array}{c}\text { Interview data (31 May 2011, } \\
19 \text { July 2011, 26 June 2012, } 18 \\
\text { September 2015 and 30 } \\
\text { November 2015)_Australian } \\
\text { Jazz Museum (AJM)—a DIY } \\
\text { popular music heritage } \\
\text { institution run exclusively by } \\
\text { volunteers, most of whom are } \\
\text { older adults and retirees. } \\
\text { A two-week period of } \\
\text { participant observation was } \\
\text { undertaken at the AJM in } \\
\text { October 2013. }\end{array}$ & & $\begin{array}{l}\text { Examine how do-it-yourself } \\
\text { (DIY) heritage institutions create } \\
\text { a sense of community and } \\
\text { promote well-being for their } \\
\text { volunteers, operating as } \\
\text { informal gathering places or } \\
\text { "third places". }\end{array}$ & $\begin{array}{l}\text { Case study—research interviews } \\
\text { were recorded and transcribed } \\
\text { verbatim, along with other data } \\
\text { sources, including field notes, } \\
\text { photographs taken during site } \\
\text { visits, and archival materials such } \\
\text { as AJM newsletters, pamphlets } \\
\text { and other ephemera were } \\
\text { imported to a qualitative software. }\end{array}$ & $\begin{array}{l}\text { Research suggests that AJM promotes } \\
\text { well-being for the, especially older, } \\
\text { volunteers who work for them. }\end{array}$ \\
\hline $\begin{array}{l}\text { Hand } \\
(2018)\end{array}$ & United Kingdom & Taking Part survey, 2012-2013. & $\begin{array}{l}\text { Arts attendance } \\
\text { (exhibition or } \\
\text { collection of art, } \\
\text { public art display } \\
\text { or installation, } \\
\text { African people's or } \\
\text { South Asian and } \\
\text { Chinese dance, and } \\
\text { other live dance } \\
\text { event included). }\end{array}$ & $\begin{array}{c}\text { Analyze the relationship } \\
\text { between arts attendance and } \\
\text { other controls and happiness to } \\
\text { vary across different levels of } \\
\text { happiness. }\end{array}$ & Quantile regression techniques & $\begin{array}{l}\text { Results show a comparatively modest, } \\
\text { but still significant, effect of arts on } \\
\text { happiness. } \\
\text { The effects of arts attendance on } \\
\text { happiness are somewhat more marked } \\
\text { in the lower quantile but they decrease } \\
\text { in the upper quantile of happiness. }\end{array}$ \\
\hline
\end{tabular}


Table 1. Cont.

\begin{tabular}{|c|c|c|c|c|c|}
\hline Authors & Geographical Scope & Source of Evidence & Focus on & Aims & Methods \\
\hline $\begin{array}{c}\text { Del } \\
\text { Saz-Salazar } \\
\text { et al. (2019) }\end{array}$ & $\begin{array}{l}\text { Contemporary Art Archives } \\
\text { and Collections of the Faculty } \\
\text { of Fine Arts of the city of } \\
\text { Cuenca (Spain) }\end{array}$ & $\begin{array}{l}\text { Survey carried out in Cuenca } \\
\text { in February } 2016 .\end{array}$ & $\begin{array}{l}\text { Art archives and } \\
\text { collections }\end{array}$ & $\begin{array}{l}\text { This article shows how } \\
\text { life-satisfaction data can be used } \\
\text { as a novel approach to value } \\
\text { cultural goods since the } \\
\text { contingent valuation method, } \\
\text { although widely used, is still the } \\
\text { subject of an intense controversy. }\end{array}$ & $\begin{array}{l}\text { Contingent valuation method, } \\
\text { Life satisfaction approach }\end{array}$ \\
\hline
\end{tabular}

Estimate the value of

Fujiwara

England
Online contingent valuation survey with library visitors and non-visitors.
Libraries

through a

valuation study of around 2000

library users and non-users.
Multivariate regression analysis to estimate the impact of library usage (having visited a library in the past 12 months) on subjective well-being.

Main Results Relevant for Our Research

Results provide evidence that the life satisfaction approach can generate meaningful values of cultural goods of use nature and non-use nature.

Library use is positively associated with subjective well-being, suggesting that libraries have an important role in users' quality of life. This study provides supporting evidence that the values for public libraries can be interpreted as reflecting primary benefits stemming from welfare changes associated with library engagement.

Structured interview administered to a sample of 100 subjects

Grossi,

Tavano

Blessi and Sanctuary of Vicoforte (Italy)

(2019) A sample of their saliva and its cortisol level measured on a visual analogous scale before and after the experience.
Investigate the effect of a highly connoted visual aesthetical experience in a heritage site in Italy in terms of certain types of biological (stress reduction) and psychological (well-being enhancement) responses.

Heritage site

Categorical variables were

Comparison of continuous variables among the different groups at follow-up was performed using one-way ANOVA followed by Bonferroni test, as appropriate.

Either Pearson or Spearman correlation, as appropriate, tested

the associations between variables.

Selection of five projects that were followed up by interviewing

Population survey in Drenthe and a field research on the

Province of Drenthe and its Otte (2019) twelve municipalities (The Netherlands) Cultural Participation Policy
'Samen Delen!' implemented from 2009 to 2012.
Analyze how art participation and social cohesion are related
Arts participation $\quad$ theoretically and what effects
art participation policy may

Arts participation $\quad$ theoretically and what effects
art participation policy may

Arts participation theoretically and what effects
art participation policy may people who organized the project.

In addition to interviewing all

In addition to interviewing, all producing participants were approached to fill out a digital survey with questions about their leisure time and social life and were interviewed once or twice, together with fellow participants in so-called focus conversations.
Aesthetic experience seems to have a noticeable impact on individual physical and mental health. In both dominions, cultural participation intensity was significantly correlated to the response.

The results show that there is mainly a correlation between passive art participation (i.e., attending events) and a bridging cohesive attitude. The correlation between active art participation (i.e., being productive in amateur art) and bridging cohesive behavior seemed to be less strong. 
Table 1. Cont

\begin{tabular}{|c|c|c|c|c|c|c|}
\hline Authors & Geographical Scope & Source of Evidence & Focus on & Aims & Methods & $\begin{array}{l}\text { Main Results Relevant for Our } \\
\text { Research }\end{array}$ \\
\hline $\begin{array}{l}\text { Wheatley } \\
\text { and } \\
\text { Bickerton } \\
(2019)\end{array}$ & United Kingdom & $\begin{array}{l}\text { Understanding Society, Waves } \\
2 \text { (2010-2011) and } 5 \\
\text { (2013-2014) }\end{array}$ & $\begin{array}{l}\text { Leisure activities, } \\
\text { encompassing the } \\
\text { arts, culture and } \\
\text { sport } \\
\text { (visits to heritage } \\
\text { sites included). }\end{array}$ & $\begin{array}{l}\text { Analyze the effect of changes in } \\
\text { subjective well-being from } \\
\text { engagement in leisure activities, } \\
\text { encompassing arts, culture, and } \\
\text { sport. }\end{array}$ & $\begin{array}{l}\text { Ordered logit, generalized } \\
\text { ordered logit, ANCOVA, and } \\
\text { change score analysis. }\end{array}$ & $\begin{array}{l}\text { Positive changes in life satisfaction } \\
\text { from increased engagement in arts } \\
\text { events, historical sites, and museums. } \\
\text { Visits to historical sites contribute to } \\
\text { positive changes in life and health } \\
\text { satisfaction. }\end{array}$ \\
\hline $\begin{array}{l}\text { Campagna, } \\
\text { Caperna } \\
\text { and } \\
\text { Montalto } \\
(2020)\end{array}$ & Italy & $\begin{array}{l}\text { "Aspetti della Vita } \\
\text { Quotidiana" (Aspects of Daily } \\
\text { Life) (AVQ) Survey, } 2014\end{array}$ & $\begin{array}{l}\text { Cultural activities } \\
\text { (Visits to cultural } \\
\text { heritage included) }\end{array}$ & $\begin{array}{l}\text { Explore the connection between } \\
\text { cultural participation and civic } \\
\text { participation. }\end{array}$ & Quantile regression model & $\begin{array}{l}\text { Results confirm that participation in } \\
\text { cultural heritage and other art and } \\
\text { cultural activities is highly correlated } \\
\text { with civic engagement. }\end{array}$ \\
\hline $\begin{array}{l}\text { Fancourt } \\
\text { and Baxter } \\
\quad(2020)\end{array}$ & England & $\begin{array}{c}\text { Taking Part survey, 2016-2017 } \\
\text { wave. }\end{array}$ & $\begin{array}{c}21 \text { receptive } \\
\text { cultural activities } \\
\text { (exhibition or } \\
\text { collection of art; } \\
\text { street arts; public } \\
\text { art dis- } \\
\text { play/installation, } \\
\text { and culturally } \\
\text { specific festival } \\
\text { included). }\end{array}$ & $\begin{array}{l}\text { Analyze whether there are } \\
\text { differential participation rates in } \\
\text { community cultural activities } \\
\text { amongst those with differing } \\
\text { levels of mental health } \\
\text { (specifically, feelings of anxiety } \\
\text { and happiness) and identify } \\
\text { potential explanatory factors. }\end{array}$ & & $\begin{array}{l}\text { Lower levels of physical and social } \\
\text { opportunity and psychological } \\
\text { capability may reduce levels of } \\
\text { cultural participation amongst } \\
\text { individuals with low levels of } \\
\text { happiness, but other physical and } \\
\text { perceived barriers still remain to be } \\
\text { explored. }\end{array}$ \\
\hline $\begin{array}{l}\text { Ateca- } \\
\text { Amestoy } \\
\text { and } \\
\text { Gorostiaga } \\
\text { (2021) }\end{array}$ & $\begin{array}{c}28 \text { countries of the European } \\
\text { Union }\end{array}$ & $\begin{array}{l}\text { Special Eurobarometer } 466 \\
\text { (2017) }\end{array}$ & Cultural heritage. & $\begin{array}{l}\text { Analyze the individual decision } \\
\text { of donating money or time to } \\
\text { support heritage organizations } \\
\text { in the } 28 \text { countries of the } \\
\text { European Union. }\end{array}$ & Bivariate probit model & $\begin{array}{l}\text { Volunteering benefits not only heritage } \\
\text { organizations but also individuals that } \\
\text { donate their time to them and may be } \\
\text { rewarded by pleasant experiences. }\end{array}$ \\
\hline
\end{tabular}




\section{Data and Methods}

\subsection{Data}

To address how different ways of access to cultural heritage and how existence of heritage relates to individual well-being, we used the data derived from the Eurobarometer 88.1 survey, conducted with a module on cultural heritage in September-October 2017, shortly before the 2018 European Year of Cultural Heritage (Special Eurobarometer 466, [38]). This module investigated engagement with cultural heritage and perceptions and attitudes of 27,881 survey respondents from the 28 EU countries, according to the following introduction of cultural heritage in the questionnaire:

"Cultural heritage is a term used to identify a range of resources that are protected, conserved or revived because they are considered worthy of passing on to future generations. Cultural heritage can mean concrete things, like monuments, archaeological sites, works of art, films, books or documents conserved and managed by museums, libraries and archives; it can also mean intangible things, like skills, rituals, music and festive events. Today, cultural heritage can also be digital, like digital art or digital reproductions of cultural heritage. Europe's cultural heritage refers to the cultural heritage from Europe and from the countries that belong to it, taken either individually or collectively" [38] (p. 85).

The module collected information on respondents' direct involvement with cultural heritage through a set of questions that, inter alia, inquired about five different ways of heritage engagement: existence, participation by visits, participation by practice, volunteering, and digital engagement. The description of the variables and the sample proportions are presented in Table 2. The availability of any type of cultural heritage, as a measure of non-use values, shows the highest sample frequency, indicating that the potential appreciation of the heritage assets is widely accessible across European countries. Visits to tangible heritage are the most popular way of accessing heritage, followed by digital access, participation in intangible heritage, and volunteering.

Table 2. Alternative forms of engagement with cultural heritage and sample proportions.

\begin{tabular}{cc}
\hline $\begin{array}{c}\text { Near where you live, are there monuments, works of art, heritage sites, traditional events or festivals that are related } \\
\text { to Europe's culture and history? }\end{array}$ & $76.00 \%$ \\
\hline Access to tangible heritage (visits to museums, monuments, libraries, and archives) & $68.50 \%$ \\
\hline Digital access / access to digital cultural heritage (search practical information, access contents, further information) & $41.45 \%$ \\
\hline Access or participation in intangible heritage (traditional performing arts, craft workshop, traditional events, \\
traditional practices, and skills) \\
\hline Voluntary work for an organization active in cultural heritage \\
\hline Source: Special Eurobarometer $466.25 \%$
\end{tabular}

\subsection{Methods}

The distribution of life satisfaction (LS) in our sample is represented in the first row of Table 3. Around $84 \%$ of the European population were (fairly or very) satisfied. The other rows show the distribution of LS according to the five heritage engagement variables. Nearly $85 \%$ of the population living near heritage resources felt (fairly or very) satisfied. When it comes to participation in tangible heritage, the percentage of the population feeling fairly or very satisfied stood at nearly $88.5 \%$, participation in intangible and in digital at $90.1 \%$, and volunteering at $93.4 \%$. 
Table 3. Row distribution of LS according to the distribution of the heritage engagement variables (percentages of the sample).

\begin{tabular}{ccccc}
\hline & LS $=\mathbf{1}$ & LS $=\mathbf{2}$ & LS = 3 & LS = 4 \\
\hline Sample distribution & 2.74 & 13.76 & 56.74 & 26.75 \\
Not nearby & 4.24 & 16.97 & 56.12 & 22.67 \\
Nearby & 2.28 & 12.77 & 56.94 & 28.01 \\
\hline Not tangible & 5.67 & 21.81 & 56.48 & 16.04 \\
Tangible & 1.40 & 10.09 & 56.86 & 31.65 \\
\hline Not intangible & 2.87 & 14.23 & 57.00 & 25.90 \\
Intangible & 1.31 & 8.61 & 53.87 & 36.22 \\
\hline Not digital & 3.94 & 17.57 & 58.00 & 20.50 \\
Digital & 1.07 & 8.42 & 54.98 & 35.54 \\
\hline Not volunteer & 2.87 & 14.2 & 57.03 & 25.81 \\
Volunteer & 0.88 & 5.74 & 52.34 & 41.03
\end{tabular}

Notes: LS $=1$ (Not at all satisfied)/LS $=2$ (Not very satisfied) $/$ LS $=3$ (Fairly satisfied) $/$ LS $=4$ (Very satisfied) Source: Special Eurobarometer 466.

To model the influence of different heritage engagement with subjective well-being, we estimated an ordered probit model with LS as a dependent variable. As explanatory variables, we considered the aforementioned five types of cultural heritage-related variables and, as controls, the following ones: gender, nationality, age, marital status, children in the household, level of education, occupation, economic difficulties, self-assessed social class, size of place of residence, and country fixed effects, and we let errors be clustered at NUTS2 level (an European regional classification) in order to capture the correlation among observations coming from the same region and potentially facing the same supply of heritage and cultural policies.

\section{Results}

Table 4 presents the estimated coefficients for the ordered probit model of life satisfaction. Statistical significance levels of the estimated coefficients are indicated with the usual asterisk convention $\left({ }^{* * *} p \leq 0.01,{ }^{* *} p \leq 0.05,{ }^{*} p \leq 0.1\right)$.

Our variables of interest were the ways of heritage engagement. In that respect, we did not find statistically significant effects for living near to a heritage resource and for practicing or engaging with intangible heritage activities. However, we found a positive association for tangible heritage access, for digital heritage access (or digital access to heritage), and for volunteering in heritage institutions. Individuals that visit heritage institutions, as museums, monuments, libraries, or archives, as well as those that access heritage digitally to enjoy it virtually or to search information, and those who do voluntary work of heritage organizations were more likely to report higher levels of life satisfaction, controlling for the effect of all other explanatory variables.

The control variables displayed the expected coefficients and coincided with welldocumented empirical regularities in the literature of subjective well-being. For instance, there was a U-shaped effect for age, such that well-being initially deteriorated with age reaching a minimum for both males and females in middle age $[12,39]$ and then increased thereafter. We further found that all marital statuses were correlated with lower life satisfaction scores when compared to being married [12]. The presence of children in the household was not statistically significant in our estimations. The level of formal education was not statistically significant except for the category of students, which was associated with higher probability of higher life satisfaction. This finding is partially due to the fact that formal education was highly correlated with the variables that explain awareness and engagement with heritage. In fact, we decided to include them in our empirical specification as they are common control variables explaining life satisfaction, though the results were robust with respect to other specifications that excluded the education explanatory variables. 
Table 4. Ordered probit model: estimation results.

\begin{tabular}{|c|c|}
\hline Variable & $\begin{array}{c}\text { Life Satisfaction } \\
\text { Coefficient }\end{array}$ \\
\hline \multicolumn{2}{|c|}{ Availability and access to heritage-related activities } \\
\hline Heritage sites or events nearby & 0.040 \\
\hline Tangible & $0.173^{* * *}$ \\
\hline Intangible & 0.115 \\
\hline Digital & $0.083 *$ \\
\hline Volunteering & $0.214^{* * *}$ \\
\hline \multicolumn{2}{|l|}{ Demographics } \\
\hline \multicolumn{2}{|l|}{ Gender } \\
\hline Man & -0.027 \\
\hline \multicolumn{2}{|l|}{ Nationality } \\
\hline Foreigner & 0.041 \\
\hline \multicolumn{2}{|l|}{ Age } \\
\hline $15-24$ & $0.292 * * *$ \\
\hline $25-34$ & $0.180 * * *$ \\
\hline $35-44$ & $0.104^{* *}$ \\
\hline $55-64$ & 0.088 \\
\hline $65-74$ & $0.165^{* *}$ \\
\hline 75 and more & $0.304^{* * *}$ \\
\hline \multicolumn{2}{|l|}{ Marital status } \\
\hline Single with partner & $-0.146^{* * *}$ \\
\hline Single & $-0.276^{* * *}$ \\
\hline Divorced or separated & $-0.351 * * *$ \\
\hline Widow & $-0.346^{* * *}$ \\
\hline \multicolumn{2}{|l|}{ Presence of children } \\
\hline Living with children & 0.053 \\
\hline \multicolumn{2}{|l|}{ Education } \\
\hline 16-19 years of schooling & 0.003 \\
\hline More than 20 years schooling & 0.29 \\
\hline Still studying & $0.300 * * *$ \\
\hline No full-time education & -0.174 \\
\hline \multicolumn{2}{|l|}{ Socio-economic status } \\
\hline \multicolumn{2}{|l|}{ Labour status } \\
\hline Self-employed & $0.186^{* *}$ \\
\hline Managers & $0.155^{* * *}$ \\
\hline White collars & $0.169^{* * *}$ \\
\hline Manual workers & 0.050 \\
\hline Unemployed & $-0.441^{* * *}$ \\
\hline \multicolumn{2}{|l|}{ Economic hardship } \\
\hline Most of the time & $-1.130 * * *$ \\
\hline From time to time & $-0.508^{* * *}$ \\
\hline \multicolumn{2}{|l|}{ Self-reported social class } \\
\hline Working class & $0.271^{* * *}$ \\
\hline Lower middle class & $-0.292^{* * *}$ \\
\hline Upper middle class & $0.370^{* * *}$ \\
\hline Higher class & $0.444 *$ \\
\hline \multicolumn{2}{|l|}{ Size of community } \\
\hline Towns and suburbs & -0.031 \\
\hline Cities and large urban areas & $-0.131^{* *}$ \\
\hline \multicolumn{2}{|l|}{ Ancillary parameters } \\
\hline /cut1 & $-2.548^{* * *}$ \\
\hline /cut2 & $-1.336^{* * *}$ \\
\hline /cut3 & $0.737^{* * *}$ \\
\hline $\mathrm{n}$ & 27,709 \\
\hline Akaike & $47,193.415$ \\
\hline
\end{tabular}

Notes: ${ }^{*} p<0.05 ;{ }^{* *} p<0.01 ;{ }^{* * *} p<0.001$ (country fixed effects and errors clustered at the NUTS2 level). Baseline categories of the explanatory variables that characterize the reference individual: woman, national, age 45-54, married, up to 15 years of schooling, out of the labor force, middle class, rural area. Controlling for variables with missing values due to answers "DK" or "Refusal". 
We found that being a worker of any type was positively associated with life satisfaction (with the highest value for self-employed, consistent with findings for European countries) and being unemployed was negatively associated [12], informing about the additional social costs of unemployment in terms of reductions of quality of life. Experiencing financial hardship was also negatively related to life satisfaction $[12,40]$ and there was a monotonic relationship between self-reported social class and life satisfaction.

In Table 5, we report the estimated marginal effects for the variables that relate to heritage valuation that turned out to be statistically significant in the ordered probit estimation (keeping all other variables in their sample means). Our results indicate that the largest change could be found in the category of being very satisfied (LS $=4$ ), with a small decrease in the predicted value of the upper category of life satisfaction ( $L S=3)$, with substantial decreases in the not very satisfied category $(L S=2)$ and only very minor changes in the predictions for not at all satisfied $(\mathrm{LS}=1)$.

Table 5. Predictive margins for heritage engagement variables (statistically significant).

\begin{tabular}{ccccc}
\hline Predictive Margins & LS = & LS $=\mathbf{2}$ & LS = 3 & LS = 4 \\
\hline Not tangible & 3.00 & 14.25 & 59.05 & 23.69 \\
Tangible & 2.20 & 11.84 & 57.65 & 28.31 \\
\hline Not digital & 2.69 & 13.08 & 58.00 & 26.23 \\
Digital & 2.36 & 12.09 & 57.33 & 28.21 \\
\hline Not volunteer & 2.63 & 12.85 & 57.68 & 26.84 \\
Volunteer & 1.78 & 10.13 & 55.22 & 32.87 \\
\hline Notes: LS = 1 (Not at all satisfied)/LS $=$ 2 (Not very satisfied)/LS = 3 (Fairly satisfied)/LS = 4 (Very satisfied).
\end{tabular}

The effect of the variables of interest indicated that visits to heritage institutions and volunteering were associated with the highest increase in the probability of being very satisfied with ones' life. The predictive margins changed from 26.84 to $32.87 \%$ for volunteering, keeping all other variables at their mean values. An interesting finding of our research is that volunteering was the less popular way of heritage engagement that we considered (the one with the lowest participation rate) but, at the same time, the most rewarding way in terms of life satisfaction enhancement. Visits to heritage institutions and elements of the tangible heritage were also associated with higher levels of life satisfaction, and we estimated that the probability of being very satisfied increased from 23.69 to $28.31 \%$ for tangible heritage. The increase in life satisfaction linked to digital access, the other variable that turned out to be statistically significant, was somehow more modest, with an increase in the category of very satisfied from 26.23 to $28.21 \%$.

\section{Discussion}

Life satisfaction (LS) is an important factor of European development, it is an objective of European policies, and, in the past decade, a growing body of literature has documented the ways in which interacting with different forms of heritage impact individual and/or community well-being [14] (p. 1300). This interest lies with the centrality of discussions and reflections on values in heritage debates and practice [1] and, particularly, with societal value perspectives that focus on uses and functions of heritage places generated by a broad range of society-wide processes external to conservation [2]. However, the measuring of this more instrumental approach to heritage that is driven by societal values is a significant challenge as convincing empirical evidence proving the relation between different ways of heritage engagement and individual subjective well-being is still scarce. As pointed out by Taçon and Baker [14] (p. 1303), much of the evidence of the impact of heritage on wellbeing is anecdotal, suggesting that even when the nexus is not measured definitively using qualitative and quantitative tools, the heritage well-being relationship can nevertheless be observed.

In order to address this lack of evidence, we explored in this article the relationships between different ways of cultural heritage engagement and LS in the European Union. 
The hypothesis that the recognition of having heritage resources nearby could be a source of LS by virtue of the non-use values of heritage cannot be supported according to this analysis. We did not find a statistically significant contribution of the existence of heritage to LS by itself. Rather, it seems that living near tangible or intangible heritage, thus the value associated to heritage existence, could indirectly contribute to quality of life by means of improving material conditions or enhancing mutual understanding, for instance through tourism [8]. Alternatively, it could be that the existence of heritage has both positive and negative effects, for example when benefits such as the creation of economic activity [41] or the possibility of enjoying a historic city or landscape cancel out with the inconveniences generated by cultural tourism due to overcrowding or gentrification, as in [26,27].

Considering the different individual alternatives for engagement, our results put into perspective previous studies that indicate that visits to heritage institutions and elements of the tangible heritage [19,35], as well as engagement in voluntary activities [12,24] increases subjective well-being. In this regard, it can be seen that heritage has contemporary value not just in economic, historic, or cultural terms, but also as a collective resource that contributes to human welfare [14] (p. 1302). While individuals visiting tangible heritage and/or donating time to heritage organizations enjoy higher levels of well-being, it would be interesting to know about the diversity of motivations that can lead to different degrees of engagement, as well as the barriers and enablers to participation [31]. Volunteering is understood to be a more committed and involved way of engagement that can contribute to individual and societal well-being through other mechanisms, such as sense of worth or belonging [42], thus benefiting not only the heritage organizations that receive the time donations, but also volunteers, as found in our research.

Our results confirm previous studies maintaining that there is evidence of important complementarities between different ways of access, as documented in this study for tangible and digital heritage access [43]. Thus, it could be the case that individuals do not benefit from the possibility of access and from engagement itself in different ways, but rather that variety and complementarities could create scope economies for the citizens that decide to participate in more than just one single dimension. The current pandemic situation has probably favored digitally mediated forms of cultural participation, that can be much more inclusive as they also reach out to people who do not regularly access arts and culture [29] (p. 676) and open new ways of access for those people in the future.

A key policy implication of our findings and resulting reflections is that greater attention should be directed to introducing more citizens to arts and cultural experiences as a life satisfaction vehicle. In that sense, the future of heritage, human well-being, and healthy societies is something of increasing importance as the world undergoes unprecedented cultural and environmental change fueled by pandemic circumstances, digital technology, global warming, and shifting political landscapes (adapted from [14]). According to them, "heritage is something that is essential for contemporary and future well-being" [14] (p. 1310), but it is also true that the ability to enjoy and take part in culture must not be taken for granted. As our findings suggest, there are financial barriers to overcome, and probably geographical, social, and cultural barriers, although they were not statistically significant in our estimations. Therefore, inclusive policies are needed to ensure that all local and foreign people can access heritage activities and therefore higher levels of subjective well-being.

This study underlines the potential of heritage engagement as a new approach to welfare policies design. The findings are consistent with past research on the impact of engagement in heritage activities on key quality of life measures. Building on this last point, national or regional exercises designed to measure overall well-being should include measures of the extent to which the population takes part in culture in general [44] and in heritage activities in particular. Although the findings confirm the association between different forms of accessing and becoming engaged with heritage and life satisfaction, a number of limitations must be noted. Firstly, being cross-sectional, this study just conveys correlation relationships, as in the vast majority of cultural participation research [31] and 
happiness studies [21]. Further longitudinal and experimental design studies would be desirable to explore causality. Secondly, qualitative mixed methods of analysis may help better understand and interpret the quantitative results that we obtained [45]. Further crosssectional research could also be carried out on the effect of frequency of participation in cultural heritage on quality of life measures. Studies exploring motives, plans, and actions of heritage policies with regard to enhancing cultural participation and tourism could add to a more comprehensive picture and potential consequences of the research. Last, our research does not fully take into account differences of heritage engagement by countries, so future studies should explore specificities at the country level. Despite the limitations, our analysis provides a methodological approach to capture the multidimensional nature of the values under investigation and the results offer interesting insights on the multiple benefits of cultural heritage.

Author Contributions: V.A.-A. worked on the concept, data analysis, and interpretation. A.V. worked on the concept, the review of the literature, and interpretation. A.J.W. worked on the concept and the policy implications. All authors have read and agreed to the published version of the manuscript.

Funding: This research was funded by the Basque Government (IT336-19), by the Spanish Ministry of Science and Innovation (PID2019-108718GB-I00) for Ateca-Amestoy, and by the Catalan Government (2017 SGR 422) for Villarroya.

Informed Consent Statement: Not applicable.

Data Availability Statement: The data presented in this study are openly available in GESIS Data Archive, Cologne at https://doi.org/10.4232/1.12959, reference number ZA6925 Data file Version 1.0.0.

Acknowledgments: This research was partly inspired by questions raised in the research project "Cultural Heritage as a Source of Societal Well-being in European Regions-ESPON HERIWELL" funded by the ESPON 2020 Cooperation Programme.

Conflicts of Interest: The authors declare no conflict of interest.

\section{References}

1. Labadi, S. Representations of the nation and cultural diversity in discourses on World Heritage. J. Soc. Archaeol. 2007, 7, 147-170. [CrossRef]

2. Avrami, E.; Mason, R. Mapping the Issue of Values. In Values in Heritage Management: Emerging Approaches and Research Directions; Avrami, E., Macdonald, S., Mason, R., Myers, D., Eds.; Getty Publications: Los Angeles, CA, USA, 2019.

3. Mason, R. Assessing Values in Conservation Planning: Methodological Issues and Choices. In Assessing the Values of Cultural Heritage: Research Report; De la Torre, M., Ed.; The Getty Conservation Institute: Los Angeles, CA, USA, 2002; pp. 5-30.

4. Fredheim, L.H.; Khalaf, M. The significance of values: Heritage value typologies re-examined. Int. J. Herit. Stud. 2006, $22,466-481$. [CrossRef]

5. Joint Programming Initiative (JPI). Cultural Heritage and Global Change HERITAGE PLUS Call. Guidelines for Applicants. 2014. Available online: http://jpi-ch.eu/wp-content/uploads/Heritage-Plus-Call-Full-Proposal-Guidelines-for-applicants.pdf (accessed on 14 April 2021).

6. European Commission. A New European Agenda for Culture. Communication from the Commission to the European Parliament, the European Council, the Council, the European Economic and Social Committee and the Committee of the Regions. (COM/2018/267 Final). 2018. Available online: https:/ / ec.europa.eu/culture/document/new-european-agenda-culture-swd2 018-267-final (accessed on 14 April 2021).

7. Frey, B.S. Arts and Economics: Analysis and Cultural Policy, 2nd ed.; Springer: Berlin/Heidelberg, Germany; New York, NY, USA, 2003.

8. Wei, Y.; Liu, H.; Park, K.-S. Examining the Structural Relationships among Heritage Proximity, Perceived Impacts, Attitude and Residents' Support in Intangible Cultural Heritage Tourism. Sustainability 2021, 13, 8358. [CrossRef]

9. Brida, J.G.; Dalle Nogare, C.; Scuderi, R. Frequency of museum attendance: Motivation matters. J. Cult. Econ. 2016, 40, 261-283. [CrossRef]

10. UNESCO. Measuring Cultural Participation. In UIS Handbook; UIS: Montreal, QC, Canada, 2013.

11. Stiglitz, J.E.; Sen, A.; Fitoussi, J.P. Report by the Commission on the Measurement of Economic Performance and Social Progress (CMEPSC), Paris. 2009. Available online: http:/ / www.stiglitzsen-fitoussi.fr/en/index.htm (accessed on 14 April 2021). 
12. Piper, A.T. Europe's capital cities and the happiness penalty: An investigation using the European Social Survey. Soc. Indic. Res. 2015, 123, 103-126. [CrossRef]

13. Maeer, G.; Robinson, A. Values and Benefits of Heritage: A Research Review; Heritage Lottery Fund Strategy and Business Development Department: London, UK, 2016; Available online: https://www.heritagefund.org.uk/sites/default/files/media/research/ values_and_benefits_of_heritage_2015.pdf (accessed on 14 April 2021).

14. Taçon, P.S.C.; Baker, S. New and Emerging Challenges to Heritage and Well-Being: A Critical Review. Heritage 2019, $2,84$. [CrossRef]

15. Ghirardi, S. Una reflexión entre Patrimonio Cultural, salud y bienestar. In 21 Assajos al Voltant del Patrimoni Cultural [21 Essays on Cultural Heritage]; Pastor Pérez, A., Picas, M., Ruiz Martínez, A., Eds.; JAS Arqueología: Madrid, Spain, 2020; pp. 94-98.

16. OECD. How's Life? 2020: Measuring Well-Being; OECD Publishing: Paris, France, 2020.

17. Council of Europe. Council of Europe Treaty Series-No. 199 Council of Europe Framework Convention on the Value of Cultural Heritage for Society (Faro Convention). 2005. Available online: https://www.coe.int/en/web/conventions/full-list/-/conventio ns/rms/0900001680083746 (accessed on 14 April 2021).

18. Fujiwara, D.; Kudrna, L.; Dolan, P. Quantifying and Valuing the Well-Being Impacts of Culture and Sport, Department of Culture, Media and Sports UK. 2014. Available online: https://www.gov.uk/government/uploads/system/uploads/attachment_data/f ile/304899 (accessed on 14 April 2021).

19. Wheatley, D.; Bickerton, C. Measuring changes in subjective well-being from engagement in the arts, culture and sport. J. Cult. Econ. 2019, 43, 421-442. [CrossRef]

20. Bryson, A.; MacKerron, G. Are you happy while you work? Econ. J. 2017, 127, 106-125. [CrossRef]

21. Hand, C. Do the arts make you happy? A quantile regression approach. J. Cult. Econ. 2018, 42, 271-286. [CrossRef]

22. Fancourt, D.; Baxter, L. Differential participation in community cultural activities amongst those with poor mental health: Analyses of the UK Taking Part Survey. Soc. Sci. Med. 2020, 261, 113221. [CrossRef]

23. Grossi, E.; Tavano Blessi, G.; Sacco, P.L. Magic moments: Determinants of stress relief and subjective wellbeing from visiting a cultural heritage site. Cult. Med. Psychiatry 2018, 43, 4-24. [CrossRef]

24. Cantillon, Z.; Baker, S. DIY heritage institutions as third places: Caring, community and wellbeing among volunteers at the Australian Jazz Museum. Leis. Sci. 2018. [CrossRef]

25. Otte, H. Bonding or bridging? On art participation and social cohesion in a rural region of the Netherlands. Poetics 2019, 76, 101355. [CrossRef]

26. Campagna, D.; Caperna, G.; Montalto, V. Does Culture Make a Better Citizen? Exploring the Relationship between Cultural and Civic Participation in Italy. Soc. Indic. Res. 2020, 149, 657-686. [CrossRef]

27. Ruiz-Blanch, A.; Muñoz-Albadalejo, J. Participación ciudadana: Del Welfare al Do It Yourself. In El Imperativo de La Participación en La Gestión Patrimonial; Sánchez-Carretero, C., Muñoz-Albadalejo, J., Ruiz-Blanch, A., Roura-Expósito, J., Eds.; Consejo Superior de Investigaciones Científicas: Madrid, Spain, 2019; pp. 41-57.

28. Ateca-Amestoy, V.; Gorostiaga, A. Donating money and time to cultural heritage: Evidence from the European Union. J. Cult. Econ. 2021. [CrossRef]

29. European Commission. Participatory Governance of Cultural Heritage. Report of the Open Method of Coordination Working Group of Member States' Experts; Publications Office of the European Union: Luxembourg, 2018.

30. Alonso González, P.; González-Álvarez, D.; Roura-Expósito, J. ParticiPat: Exploring the Impact of Participatory Governance in the Heritage Field. PoLAR Political Leg. Anthropol. Rev. 2018, 41, 306-318. [CrossRef]

31. Bakhshi, H.; Fujiwara, D.; Lawton, R.; Mourato, S.; Dolan, P. Measuring Economic Value in Cultural Institutions; Arts and Humanities Research Council: London, UK, 2015.

32. Fujiwara, D.; Lawton, R.N.; Mourato, S. More than a good book: Contingent valuation of public library services in England. J. Cult. Econ. 2019, 43, 639-666. [CrossRef]

33. Del Saz-Salazar, S.; Navarrete-Tudela, A.; Alcalá-Mellado, J.R.; del Saz-Salazar, D.C. On the use of life satisfaction data for valuing cultural goods: A first attempt and a comparison with the Contingent Valuation Method. J. Happiness Stud. 2019, 20, 119-140. [CrossRef]

34. Sanetra-Szeliga, J.; Górniak, A. Wpływ Projektów Infrastrukturalnych z Zakresu Kultury Zrealizowanych w Małopolsce na Otoczenie Społeczno-Gospodarcze. Raport z Badań (Impact of Infrastructure Projects in the Field of Culture Implemented in Małopolska Region on the Socio-Economic Environment. Report). 2018. Available online: https://www.obserwatorium.malopo lska.pl/wp-content/uploads/2018/10/Raport-Wp\%C5\%82yw-projekt\%C3\%B3w-infrastrukturalnych-z-obszaru-kultury-na -otoczenie-spo\%C5\%82eczno-gospodarcze-1.pdf (accessed on 14 April 2021).

35. Steiner, L.; Frey, B.; Hotz, S. European capitals of culture and life satisfaction. Urban Stud. 2013, 52, 374-394. [CrossRef]

36. Adie, B.A.; Falk, M.; Savioli, M. Overtourism as a perceived threat to cultural heritage in Europe. Curr. Issues Tour. 2020, 23, 1737-1741. [CrossRef]

37. Adie, B.A.; Falk, M. Residents' perception of cultural heritage in terms of job creation and overtourism in Europe. Tour. Econ. 2020. [CrossRef]

38. European Commission. Special Eurobarometer 466. October 2017. Report. Cultural Heritage. Available online: https:// europa.e u/eurobarometer/surveys/detail/2150 (accessed on 14 April 2021). 
39. Blanchflower, D.G. Is happiness U-shaped everywhere? Age and subjective well-being in 145 countries. J. Popul. Econ. 2021, 34, 575-624. [CrossRef] [PubMed]

40. Shields, M.A.; Price, S.W. Exploring the economic and social determinants of psychological well-being and perceived social support in England. J. R. Stat. Soc. Ser. A Stat. Soc. 2005, 168, 513-537. [CrossRef]

41. Škrabić Perić, B.; Šimundić, B.; Muštra, V.; Vugdelija, M. The Role of UNESCO Cultural Heritage and Cultural Sector in Tourism Development: The Case of EU Countries. Sustainability 2021, 13, 5473. [CrossRef]

42. Meier, S.; Stutzer, A. Is Volunteering Rewarding in Itself? Economica 2008, 75, 39-59. [CrossRef]

43. Ateca-Amestoy, V. Alternativas de acceso al patrimonio cultural de los ciudadanos europeos. Cuad. Económicos de ICE 2019, 98, 43-61. [CrossRef]

44. Leadbetter, C.; O'Connor, N. Healthy Attendance? The Impact of Cultural Engagement and Sports Participation on Health and Satisfaction with Life in Scotland; Scottish Government Social Research: Scotland, UK, 2013. Available online: https://www.gov.scot/publicati ons/healthy-attendance-impact-cultural-engagement-sports-participation-health-satisfaction-life-scotland/ (accessed on 14 April 2021).

45. Reilly, S.; Nolan, C.; Monckton, L. Wellbeing and the Historic Environment. Threads, Issues and Opportunities for the Historic Environment. Historic England. 2018. Available online: https://historicengland.org.uk/images-books/publications/wellbeing -and-the-historic-environment/wellbeing-and-historic-environment/ (accessed on 14 April 2021). 